\title{
Petrography and Mapping of the Gwal Melange of Khanozai Region, Balochistan, Pakistan
}

\author{
a Centre of Excellence in Mineralogy, University of Baluchistan, Quetta \\ ${ }^{\mathrm{b}}$ Geological Survey of Pakistan, Quetta \\ *Corresponding Author: Email: kakarmi.cemuob@gmail.com
}

Muhammad Panezaia, Muhammad Ishaq Kakara*, Umar Farooq ${ }^{b}$, Nisar Ahmed ${ }^{b}$, Khawar Sohail ${ }^{b}$

\section{DOI: 10.2478/pjg-2020-0001}

\begin{abstract}
:
The Gwal mélange is mapped on a large scale and is divided into the lithological units such as ultramafic, mafic, volcanic, volcanoclastic rocks, pelagic sediments and ophicarbonates. Petrographically, the mapped rocks are classified as harzburgite, dunite, wehrlite, serpentinite, gabbro, basalt, and andesite. These rocks are quite deformed and altered into the secondary minerals. Harzburgite is a layered mantle peridotite consists of olivine and orthopyroxene while dunite lacks the presence of any pyroxene. Serpentinite is the secondary product after peridotite is the product of post magmatic stages. The mesh structure is usually observed when olivine is completely altered to serpentine. The volcanic rocks are structurally sheeted and pillow type while the volcanoclastic rocks are essentially hyaloclastites associated with pelagic sediments. The Ophicarbonate is composed of serpentinite fragments and carbonate minerals, most probably calcite. Minor to trace amounts of opaque minerals are also present in association with major components. The gabbros may be a fragment of the main crustal rocks and have been formed in a magma chamber by fraction crystallization. The origin of ophicarbonate may be due to gas seeps originated by mantle or as the surficial process where ultramafic rocks and carbonates are mixed through processes of gravity, tectonic crushing and sedimentary reworking. The Gwal mélange may the southern extension of Bagh Complex found beneath the Muslim Bagh Ophiolite. The mantle peridotite of the mélange is much like that of the Khanozai peridotite and may represent its detached blocks. Volcanic and volcanoclastic rocks may be the representatives of the uppermost part of ophiolite crust which might have trimmed off from subducting slab and are, now, part of the Gwal accretionary wedge. The mélange may have tectonically emplacement over the Indian platform sediments along with overlying the ophiolite sheet during the Late Cretaceous.
\end{abstract}

Keywords: mélange, ultramafic-mafic units, volcanics-volcaniclastics rocks, ophicarbonate.

\subsection{Introduction:}

Alongside ophiolites, mélanges exist for the most part in collisional and accretionary belts and display mappable topographical arrays, containing differentiating age and source encased in shaly, arenaceous or serpentinite network. They normally show highly stratal distortion and a disordered internal structure. The name mélange has advanced to cover tectonics, sedimentary, as well as diapiric exercises since its initial use [1]. Discussion on defining mélange started after, who suggested the term "mélange" only for tectonic one after his work in Franciscan Complex [2]. Mélange generation has been associated with three different tectonic regions, oceanic fracture zone in abyssal setting, subduction initiation related and subduction-accretion complex related in collisional settings [3]. Based on geochemical evidence, described the mélange as block in-matrix evolution in serpentinite situated within the confines of an abyssal fracture zone [4]. Some researchers further illuminated the subduction inception on the changeable sole rocks of (Vourinos and Pindos) ophiolites in Greece [5].

In Pakistan, the ophiolite mélange is comprised of blocks of sedimentary, oceanic igneous rocks, and metamorphic sole rocks occurring underneath the basal ophiolite thrust [3,6]. It is accreted during the final stage of ophiolites' emplacement and is very significant in the reconstruction of the tectonic history of an ophiolite complex $[5,6]$. In Balochistan, the mélanges are representing the lower unit of the ophiolite complexes and are determined to be found beneath the major ophiolites in Balochistan; e.g., Bela Ophiolite and Muslim Bagh Ophiolite [6, 9]. The nature and composition of the mélanges exposed beneath the Zhob and Khanozai ophiolite are awaited to report. The Gwal mélange is an accretionary wedge complex exposed southwest of the Khanozai Ophiolite. It is studied in reconnaissance, is comprises of large blocks of serpentinized peridotites, gabbros, volcanic rocks and pelagic sedimentary rocks $[9,10]$. As the studies available on Gwal mélange is of preliminary nature and its detailed study both in the field and in the laboratory was required. This paper discusses the distribution of the mapped units and classification of the identified rocks in the mélange through their field features and petrographic characterization.

\subsection{Regional Geology}

Tectonically, the geology of the Gwal area can possibly be divided into three different geological terranes. These are Pishin Flysch belt, Khanozai-Muslim Bagh ophiolite complex occupying the suture zone and the Calcareous belt from north to south. These terranes were initially divided into the Flysch zone, Axial zone and Calcareous zone [11].

The Pishin flysch and ophiolite suture belts are divided into six different tectonostratigraphic zones [12]. The oldest of them, and at the base is the Muslim Bagh ophiolite of late Cretaceous age. Zone I of tectonostratigraphic zones of poses excellent exposers in the vicinity of Zhob valley, located northeast of Quetta. The widely exposed outcrops of Muslim Bagh ophiolite is the southeastern extended strip of ophiolitic belt consisting of Bela, Muslim Bagh, Zhob, and Waziristan, occupying northwestern extremity of Indian Continental Plate, $[13,14]$. The Muslim Bagh Ophiolite is a segment of Neo Tethys which later on obducted on Indian Plate's leading-edge during wiping out of Neo-Tethys and impact in Cretaceous-Tertiary boundary of the well-known Eurasian plate [11,15-18]. The ophiolite was emplaced 65-70 Ma and compositionally consists of a complete ophiolitic suite from ultramafic tectonites, cumulates, gabbro pillow basalts and overlying pelagic sediments [18]. The geochemistry, of the crustal rocks of the ophiolite, suggests forming in a suprasubduction tectonic setting [19]. Nisai Formation, of Eocene age, non-conformably overlies the Muslim Bagh Ophiolite, while a mélange called as 'Bagh Complex' underlies this ophiolite sequence [20]. The Khanozai ophiolite consists of an ophiolitic rock sequence that underlies metamorphic rocks and mélange; comprising of volcanic to volcanoclastic rocks [21]. The ophiolite sequence is primarily composed of mantle peridotite and ultramafic to mafic crustal rocks. The rocks of the mantle section are predominantly tectonized harzburgite and a minor proportion of dunite containing segregated chromitite deposits [22-24]. While the crustal section of Khanozai Ophiolite comprises of both ultramafic and mafic cumulates. Ultramafic cumulates are composed of repeated successions of dunite, pyroxenite, and wehrlite. While the mafic cumulates are foliated and layered gabbros [24,25].

The Calcareous belt consists of Mesozoic to Paleogene sequence, which is clearly traceable along the northwestern edge of the Indian continent in Pakistan. Tethys Ocean, forming multiple thrusts and fold belts of nearly $100 \mathrm{~km}$ wide in the Sulaiman, Kirthar and Salt Range [25,26]. The Calcareous belt consists of Dungan Formation of Paleocene age, Mona Jhal Group and Alozai Group [27]. Mona Jhal Group consists of Sembar, Goru, Parh, Bibai, and Mughal Kot formations ranging in age from Early-Late Cretaceous. Alozai Group further consists of Spingwar and Loralai Formations of Early Jurassic age (Figure 1). 


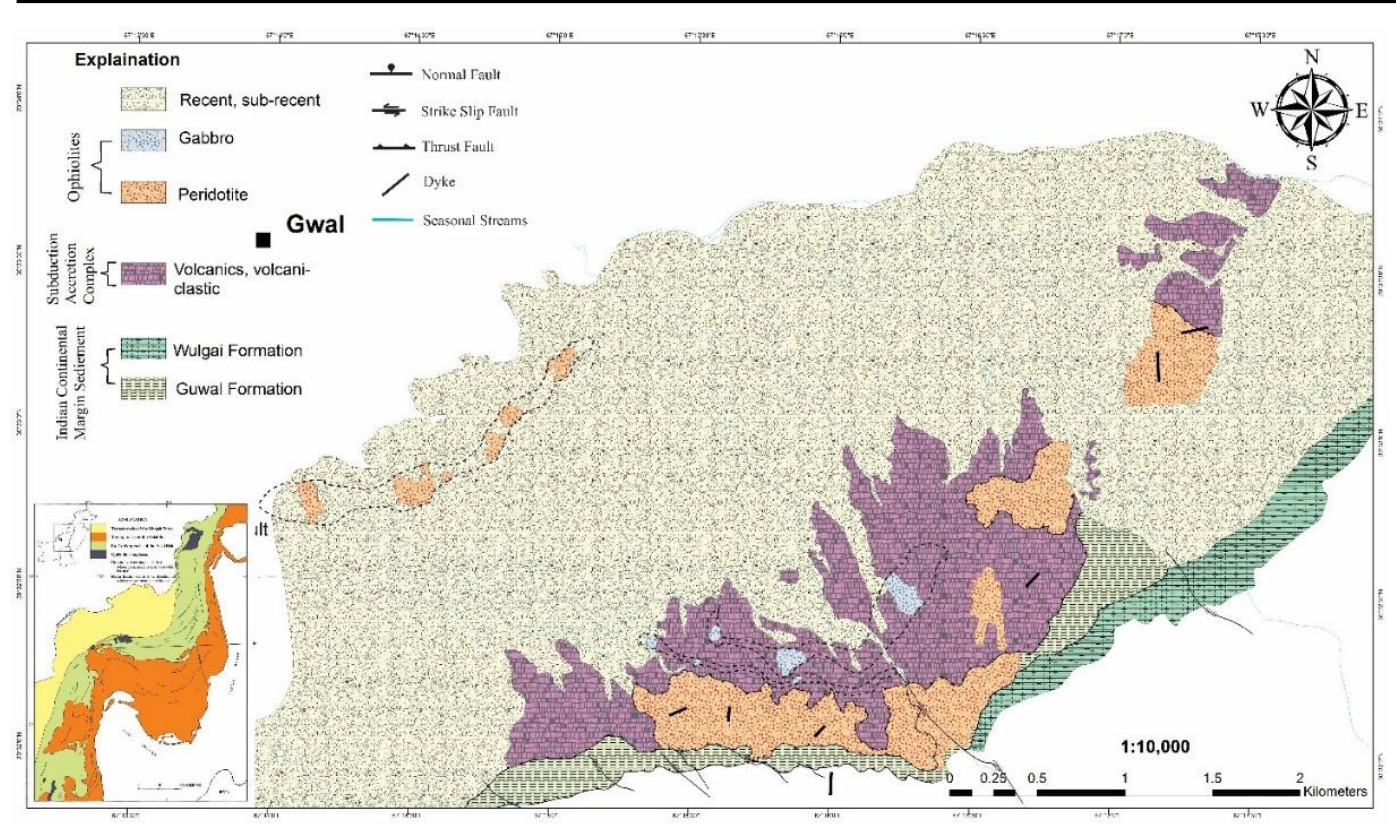

Figure 1: Geological map of Gwal mélange.

\subsection{Material and method}

Detail field excursion was conducted to note field features, collect samples and prepare a detail geological map differentiating all different mélange units in the area. Geological tools like Geological hammer, measuring tape and Brenton compass were used in the field to obtain proper field features like dip, strike, the orientation of the different units. Based on field observations, contacts of different mélange units were marked and 50 oriented and geo-referred samples were collected and out of which 22 were prepared for thin section study. The Geological Survey of Pakistan (GSP), Quetta, provided facilities for thin section preparation. Thin section petrographic study was carried out through Leica DM750 polarizing microscope, at Petrology Mineralogy Branch, GSP, Quetta. Photomicrographs, texture and percentage calculation were accurately measured and calculated through (Leica suit) registered application installed with DM750 microscope. The graphics work is performed with Coral Draw X19 and Arc GIS.
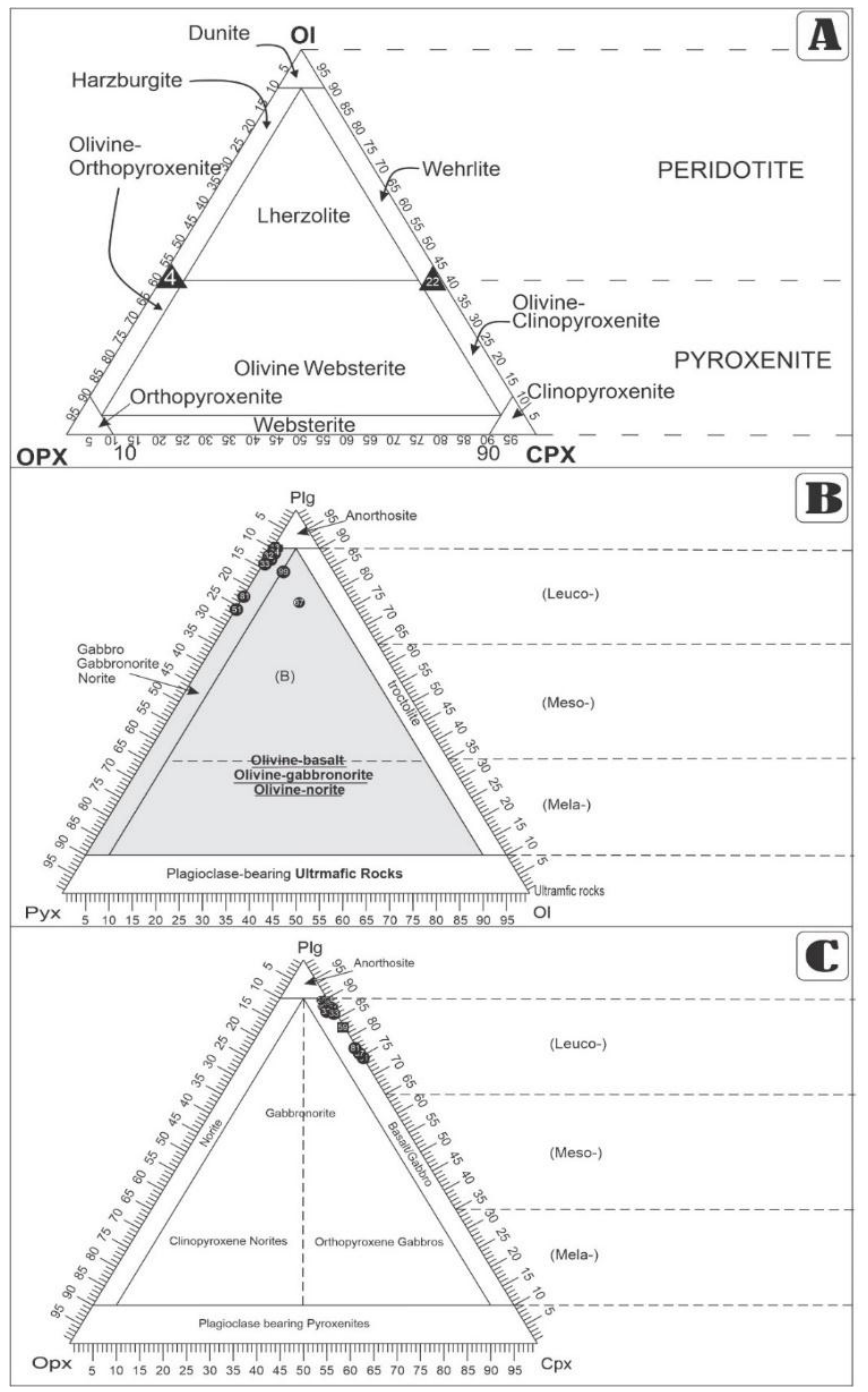

Figure 2: IUGS Diagram shows the classification of (a) Ultramafic (b, c) mafic rocks. 


\subsection{Results}

4.1. Field Observations

The Gwal mélange is located east of the Gwal village, which is $63 \mathrm{~km}$ northeast of Quetta, Baluchistan. The total area covered by the mélange is $15 \mathrm{~km} 2$. Gwal mélange being part of Khanozai Ophiolite Complex lies beneath the Khanozai ophiolite in the northern Baluchistan. Detail mapping and petrographic studies have confirmed their different rock compositions and extents. Isolated bodies along the roadside are mostly serpentinized, however, one of the 6 outcrops of these isolated bodies is petrographically confirmed as harzburgite. These outcrops are mostly covered by recent alluvium. Most of the Gwal mélange area consists of basalt intruded by gabbros. Unaltered basalt possesses both pillow and sheet structures, which are cut across by magmatic, dykes at places. The southeastern portion of the mélange consists of mantle peridotites mostly altered into serpentinites (Figure 1). Few pegmatitic dykes (probably idingsite/rhodingite) are also present.
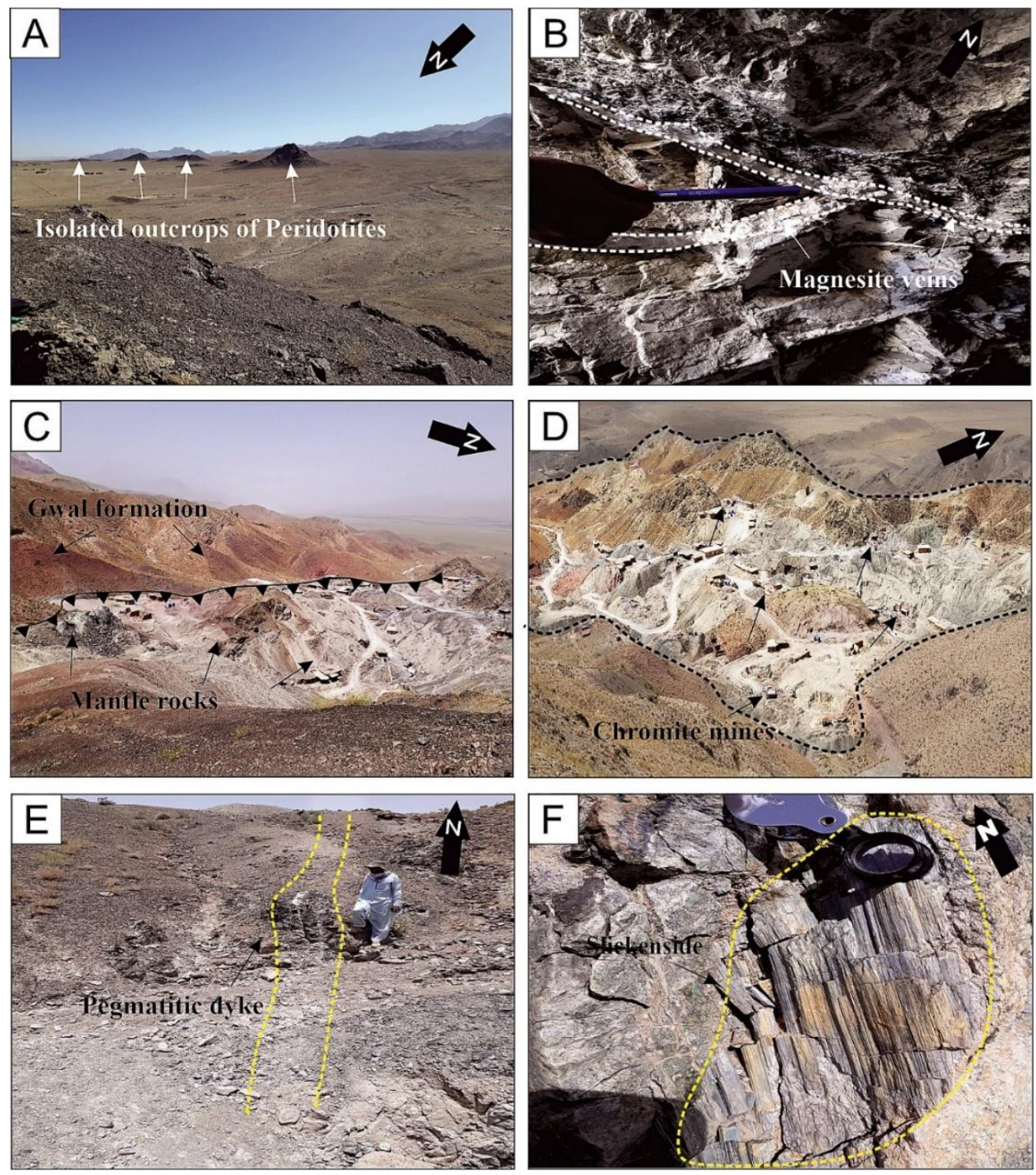

Figure 3: Field features of the rocks of Gwal mélange: (A) isolated outcrops of peridotite, (B) magnesite veins in the harzburgite, (C) The Gwal Formation (Triassic) thrusted over the back on the mantle rocks. (D) Extensive chromite mining in the area. (E) Pegmatite dyke in ultramafic rock. (F) Slickenside marks over the rock portion showing thrusted tectonics.

The Peridotites in Gwal mélange are distributed along the roadside and to the southeast of the Zhob-Quetta National Highway. Four to five small outcrops of ultramafic rocks are present adjacent to Quetta-Zhob National Highway (Figure 3A). Petrography shows that these rocks are mostly altered to serpentine however an isolated body of harzburgite is also present. In the westernmost part of Gwal mélange, these mantle rocks show interlaying of harzburgite and dunite. The fresh surface of these serpentinites is olive green, however, the weathered surface usually appears black. The fresh surface color of dunite is similar to that of serpentinite, however, weathering imparts grey to yellowish/reddish-grey coloration. These exposures are northeast-southwest oriented, well-bounded and highly jointed with multiple sets of joints. Magnesite veins are found in a few outcrops of peridotite (Figure 3B). In the southern part of the mélange, the peridotite is thrusted back by the Gwal Formation of the Indian continent margin sediments probably and is underlain by the volcanic rocks (Figure 3C). The uppermost part of mantle rocks is mainly chromite bearing dunitic rich zone, severely altered into serpentinite (Figure 3D). Many dolerite/rhodingite and small/thin diorite veins and dykes are intruding the mantle rocks. (Figure 3E). these dykes/veins possess very clear evidence of the movement of blocks in the form of slickensides (Figure 3F).

The volcanic rocks of the Gwal mélange present as separate small rounded hills with low elevation. These rocks are over thrusted by mantle peridotite. (Figure 4A). Most of these outcrops are highly deformed which destroyed their internal structural, however, at places, both the sheet and pillow structures are present (Figure 4B-C). Evidence of thrust and deformational movement like slickensides is common. Plutonic rocks of the Gwal mélange are extremely weathered. Their fresh color is dull to light green, while weathered color is dull earthy to light brown. At places, their crystal size is large enough that is visible with the naked eye. They are present as an intrusion in volcanic rocks (Figure 4A and D). The typical layered gabbro of the ophiolitic sequence is not found in Gwal mélange but they are present sporadically in a linear pattern within basaltic sequences. In the Gwal mélange, besides large block of the mantle and volcanic rocks, some volcanoclastic and pelagic sedimentary rocks are also present (Figure 4E). Lithologically, the sedimentary rocks are mudstone, shale, chert, and pelagic limestone (Figure 4F). These lithologies are red, maroon, brown, and green to grey in color. These volcanoclastic rocks 
are quite altered and deeply weathered. Main exposers/are found in the area otherwise they are mostly covered by scree.
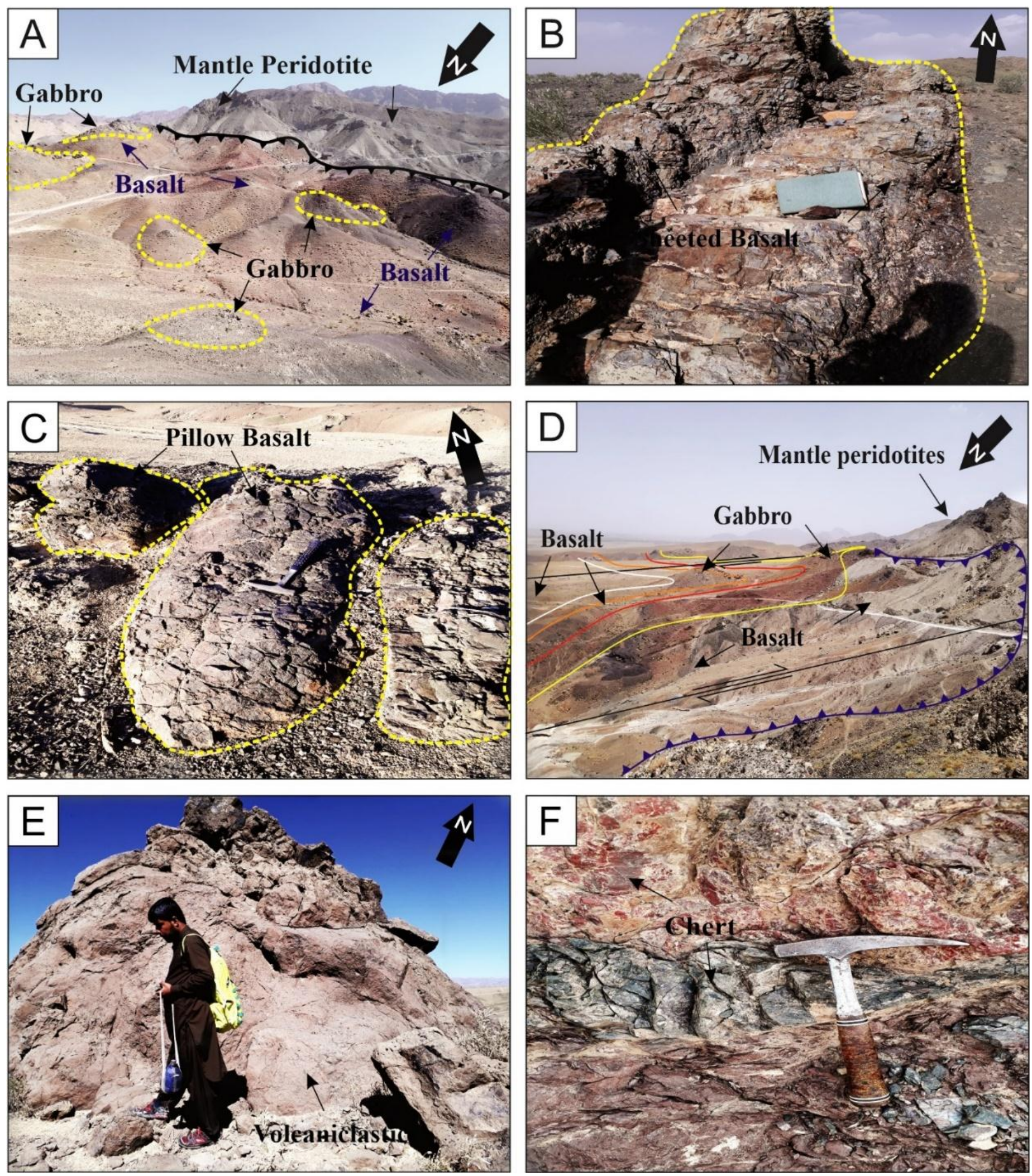

Figure 4: Field features of the rocks of Gwal mélange: (A) ultramafic rocks thrusted over volcanic rocks, (B) sheeted basalt in the mélange, (C) pillow basalt, (D) gabbro, (E) volcanoclastic rocks, (F) basalt and chert in the area.

\subsection{Petrography}

\subsection{Peridotite}

The studied samples are essentially composed of mafic minerals. These rocks are medium to coarse-grained $(180-224 \mu \mathrm{m})$ and heterogeneous in modal mineralogy. Sample-4 is composed of olivine and orthopyroxene, while in sample-22 olivine and clinopyroxene occur as essential minerals. Both samples are intensively serpentinized, in which serpentine is developed both as mesh after olivine and as bastite after orthopyroxene. Serpentine is also developed along with fractures that cross-cut the sample at a thin-section scale. The modal mineralogy of the studied samples is given in table 1 . According to the IUGS classification of ultramafic rocks, sample-4 falls in the category of harzburgite, while sample-22 lies in the field of wehrlite (Figure 5A). 

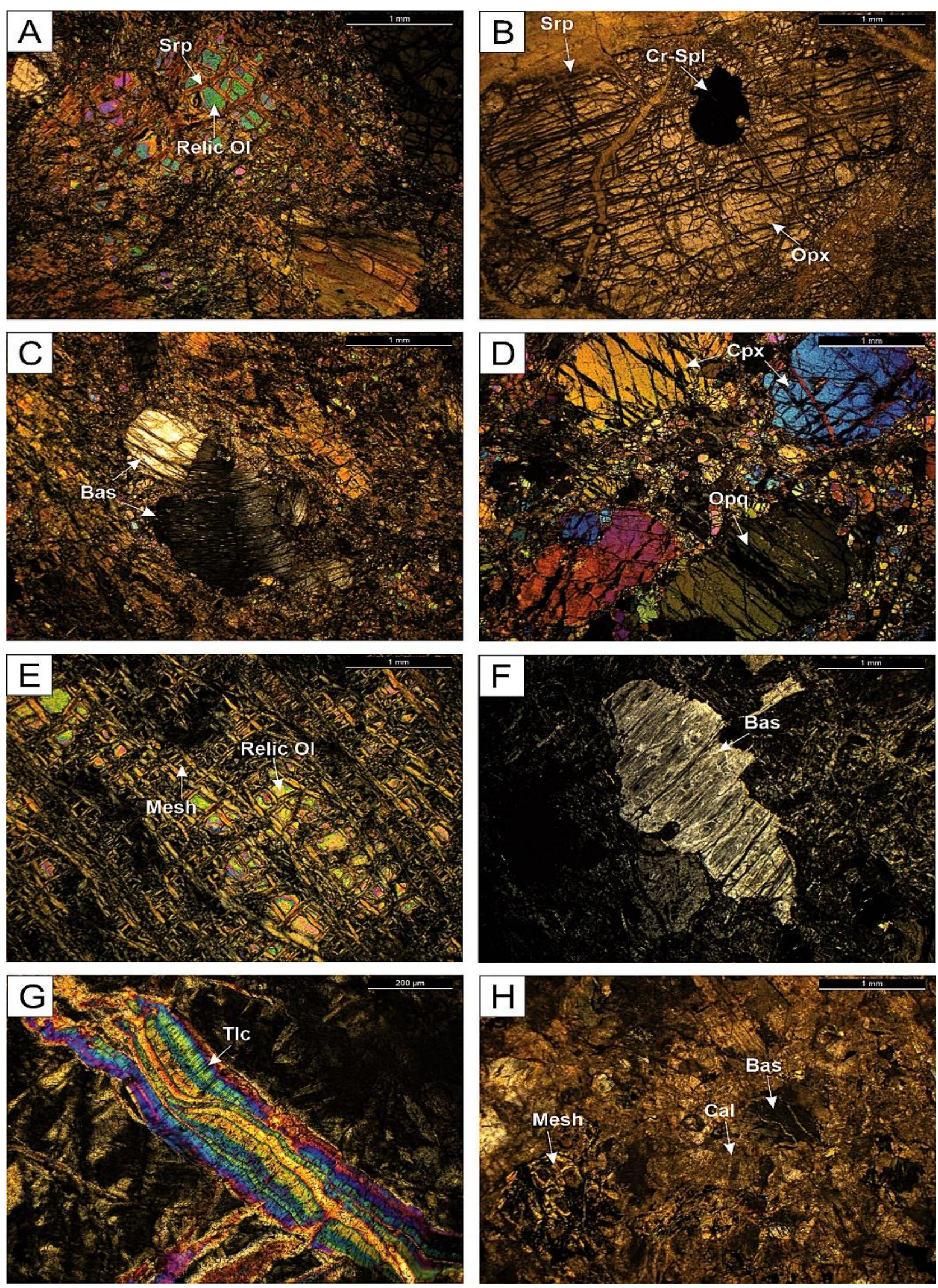

Figure 5: Petrographic features of the rocks of Gwal mélange: (A) relic olivine (Ol) and serpentine (Srp), (B) serpentine (Srp) chromium Spinel (Cr Sp) and orthopyroxene (Opx), (C) bastite (bas), (D) clinopyroxene (cpx) and opaque grains (Opq), (E) relic olivine (Ol) and mesh, (F) bastite (bas), (G) talc (Tlc), (H) mesh, calcite (Cal) and bastite. The mineral abbreviations are after Whitney and Evans, (2010).

Table 1: Modal mineralogy of the rock samples from Gwal mélange.

\begin{tabular}{|l|l|l|l|l|l|l|l|l|l|}
\hline \multicolumn{2}{|l|}{ Ultramafics } & & & & & & & & \\
\hline Sample & 0l & 0px & Cpx & Srp & Bas & Bwl & 0pq & Cr-Sp & Tlc \\
\hline $\mathbf{4}$ & 15 & 22 & 0.5 & 45 & 10 & 5 & 0.5 & 0.5 & 1 \\
\hline
\end{tabular}




\begin{tabular}{|c|c|c|c|c|c|c|c|c|c|}
\hline 22 & 30.00 & 0.50 & 44.67 & 18.33 & 0.00 & 1.00 & 3.83 & 0.00 & 1.33 \\
\hline \multicolumn{10}{|c|}{ Serpentinite } \\
\hline \multirow[t]{2}{*}{ Sample } & \multicolumn{2}{|c|}{ Serpentine } & \multirow[t]{2}{*}{ Ol } & \multirow{2}{*}{$\begin{array}{l}\text { Cr- } \\
\text { Sp }\end{array}$} & \multirow[t]{2}{*}{ Opq } & \multirow[t]{2}{*}{ Tlc } & & & \\
\hline & Mesh & Bastite & & & & & & & \\
\hline 2 & 88 & 0 & 10 & 0 & 2 & 0 & & & \\
\hline 5 & 98 & 0 & 0 & 0 & 2 & 0 & & & \\
\hline 15 & 86 & 10 & 0 & 1 & 2 & 1 & & & \\
\hline 16 & 98 & 0 & 0 & 0 & 2 & 0 & & & \\
\hline \multicolumn{10}{|c|}{ Ophicarbonates } \\
\hline \multirow[t]{2}{*}{ Sample } & \multicolumn{5}{|c|}{ Serpentinite fragment } & \multirow[t]{2}{*}{ Cal } & \multirow[t]{2}{*}{ Opq } & \multirow[t]{2}{*}{ Rt } & \\
\hline & $\begin{array}{l}\text { Srp } \\
\text { (Mesh) }\end{array}$ & $\begin{array}{l}\text { Srp } \\
\text { (Bastite) }\end{array}$ & Opq & Tlc & Idn & & & & \\
\hline 41 & 45 & 12 & 3 & 0.5 & 0.3 & 38 & 0.3 & Trace & \\
\hline \multicolumn{10}{|l|}{ Gabbro } \\
\hline Sample & $\mathbf{P l}$ & Cpx & Opq & Chl & $\operatorname{Tr}$ & & & & \\
\hline 34 & 62.8 & 8 & 12.2 & 13 & 4 & & & & \\
\hline 37 & 69.34 & 10 & 4.66 & 11 & 5 & & & & \\
\hline 38 & 81.9 & 10 & 0.1 & 8 & 0 & & & & \\
\hline 44 & 77.9 & 11.33 & 1.77 & 9 & 0 & & & & \\
\hline 59 & 74 & 11 & 8 & 7 & 0 & & & & \\
\hline 64 & 77.56 & 12 & 2.44 & 8 & 1 & & & & \\
\hline \multicolumn{10}{|l|}{ Basalt } \\
\hline Sample & PI & Cpx & Opq & Chl & Bt & Afs & Ser & $\operatorname{Tr}$ & \\
\hline 32 & 60 & 9 & 5 & 20 & & 4 & 2 & & \\
\hline 33 & 62 & 10 & 6 & 15 & & 5 & 2 & & \\
\hline 51 & 57 & 20 & 5 & 10 & & 4 & 2 & 2 & \\
\hline 81 & 66 & 20 & 1 & 10 & 0.5 & 3 & 0 & & \\
\hline 98 & 52 & 7 & 15 & 10 & & 5 & 1 & 10 & \\
\hline \multicolumn{10}{|c|}{ Olivine Basalt } \\
\hline Sample & PI & Cpx & Opx & Chl & Afs & Ol & Ser & $\operatorname{Tr}$ & Cal \\
\hline 67 & 67 & 10 & 0.1 & 6.4 & 3 & 12 & 1 & 0.5 & \\
\hline 99 & 72.96 & 10 & 2.44 & 6.6 & 3 & 6 & 1 & & Trace \\
\hline 100 & 75.6 & 11.33 & 1.77 & 7.1 & 3 & 0.5 & 1 & & \\
\hline \multicolumn{10}{|l|}{ Andesite } \\
\hline Sample & PI & Cpx & Opq & Chl & Bt & Afs & Ser & & \\
\hline 13 & 76 & 9 & 11 & 2 & 1 & 5 & 1 & & \\
\hline
\end{tabular}

Olivine in harzburgite occurs in the form of relics only because of the meshed-texture of serpentine cross-cut all the olivine grains (Figure 2A). Orthopyroxene is anhedral to subhedral, highly fractured and altered to serpentine along with these fractures (Figure 5B). The grain size ranges from (855$2241 \mu \mathrm{m}$ ), and the most dominant size is $(900-1200 \mu \mathrm{m})$. Orthopyroxene-bastite grains (Figure 5C) occur in accessory amount and their grain size ranges from $(400-700 \mu \mathrm{m})$. Clinopyroxene occurs in trace amount, it is subhedral in form and its size is less than 1 millimeter. The trace amount of Cr-spinel (Figure 5B) is also present and its grain size ranges from $(100-400 \mu \mathrm{m})$. It exhibits its characteristic reddish-brown color and isotropic behavior, it is also cross cut by very thin serpentine veins.

The clinopyroxene is the most abundant mineral in wehrlite, it is mostly coarse-grained and subhedral to anhedral in the form (Figure 5D). Its grain size ranges from $(505-1613 \mu \mathrm{m})$, and the dominant size range is $(700-1000 \mu \mathrm{m})$. Olivine is the second most abundant mineral, it is cross-cut by serpentine however the intensity of serpentinization is relatively less than in harzburgite. Clinopyroxene grains are highly fractured and opaque mineral(s) occur as filling material (Figure 5D). Exsolutions, in the form of lamellae and blebs, are also present in a few grains. Opaque mineral(s) occur in accessory amount, these are mostly anhedral and their grain size ranges from $(100-200 \mu \mathrm{m})$.

\subsection{Serpentinite}

These rocks are mostly composed of serpentine, while minor proportions of relic olivine, Cr-spinel, opaque mineral(s) (most probably magnetize and/or chromite), and talc are also present. Relic olivine grains (Figure 5E) of variable sizes are preserved in only one sample (sample-2), and their grain size ranges from less than 50 micrometers to 300 micrometers. While the orthopyroxene-bastite (Figure $5 \mathrm{~F}$ ) is also present in one sample only (sample-15) and the presence of $\mathrm{Cr}$-spinel is also restricted in the same sample. Hourglass habit of the serpentine is very poorly developed in some samples, however, the serpentine flakes in this texture are very fine-grained and their optical description is very difficult to explain. Cr-spinel exhibits its characteristic reddish color and cross-cut by very thin veins containing serpentine. Talc occurs in the form of very thin veins, up to 250 micrometers thickness (Figure 5G), and its presence as direct alteration from olivine or other Mg-rich minerals is not evident in any of the studied samples.

\subsection{Ophicarbonate}

The studied sample is predominantly composed of serpentinite fragments and carbonate mineral(s), most probably calcite. Minor to trace amounts of opaque mineral(s) and rutile are also present in association with major components. Texturally, the serpentinite fragments are brecciated with moderately to highly angular faces and their size ranges from 0.1 millimeters to 4 millimeters. These fragments can further be divided into two different textural classes; 
a) fragments mainly composed of meshed-serpentine (Figure $5 \mathrm{H}$ ) with a minor amount of very fine-grained opaque mineral(s) and trace amounts of talc and iddingsite, and b) orthopyroxene-bastite fragments (Figure 5H). The modal abundance of type (a) fragments is 48 percent, in which the modal abundance of very fine-grained opaque mineral(s) is 3 percent and their presence is restricted to very thin fractures only. While type (b) makes only 12 percent of the modal mineralogy. Meshed-serpentine fragments are very heterogeneous in size and range from 0.1 millimeters to more than 4 millimeters, while bastite fragments size ranges from 0.5 millimeters to 2.5 millimeters. Talc occurs as well-developed flakes within both type (a) and (b) fragments, however, its occurrence, as very thin veins is restricted within type (a) only. The modal abundance of carbonate mineral(s) is 38 percent. The studied sample is not stained with a solution, therefore, the exact identification of these minerals is not given in this study, however, the presence of calcite and/or is most likely (Figure $5 \mathrm{H}$ ). Its grains are mostly anhedral to subhedral and their size ranges from 0.4 millimeter to 1.5 millimeters. These minerals are also partially micritized at places, however, the process of micritization is not very intensive. Rutile and other opaque minerals (s) occur in trace amounts, these are mostly anhedral and very fine-grained.

\subsection{Gabbro}

Texturally, gabbroic rocks of Gwal mélange are phaneritic and their grain size varies from medium to coarse-grained and ranges from 0.5 to $2 \mathrm{~mm}$, however, the most dominant population of grain size is 1 to $1.3 \mathrm{~mm}$. The majority of the grains are subhedral to euhedral therefore represent a hypidiomorphic texture (Figure 6A). These rocks are primarily composed of plagioclase and clinopyroxene as essential minerals, while minor to accessory proportions of olivine, amphibole, biotite, and opaque phase(s) are, also present. Chlorite, tremolite/actinolite, iddingsite, talc, sericite, andalusite, epidote, and zoisite exist as alteration products after primary phases.

Plagioclase is, mostly, subhedral to euhedral lath shaped, and its grain size ranges from $0.5 \mathrm{~mm}$ to $2.3 \mathrm{~mm}$, and the majority of the grains are $1 \mathrm{~mm}$ to 1.3 $\mathrm{mm}$ in size. Lath shaped grains are abundant with a minor proportion of needle-like, and stubby equidimensional grains. Later two types are mostly interstitial to first type. Carlsbad twinning is most common, and albite polysynthetic twinning is rarely present in a few grains. Clinopyroxene is an essential component of these samples. Its grain size is relatively smaller than plagioclase and ranges from 0.15 to 1.2 millimeters and the most dominant size range is 0.4 to 0.7 millimeters. It occurs as well developed euhedral prismatic grains to poorly developed anhedral grains. The contact relationship of the euhedral clinopyroxene with plagioclase suggests that the euhedral generation of clinopyroxene might be the oldest in the crystallization sequence. It is also supported by the presence of euhedral inclusions of clinopyroxene in the well-developed lath shaped plagioclase grains (Figure 6B). This generation of clinopyroxene grain is intensively altered into chlorite and ferro-actinolite (Figure 6C). Euhedral to subhedral opaque phase(s) occur in a negligible amount, and in a few samples, it exhibits skeletal morphology. The trace amount of olivine is observed in one sample only, and the very minor amount of iddingsite is also present in the same sample. Talc pseudomorphs after olivine are also present, these grains make convex contact with the clinopyroxene (Figure 6D), and therefore they are older in the crystallization sequence. Chloritized hornblende and biotite occur in trace amounts.

\subsection{Balsalt}

Basalt samples are fine-grained, hypidiomorphic, and a few samples also contain phenocrysts of its essential minerals. Occasionally these phenocrysts are clustered together and depict glomeroporphyritic texture (Figure 6E). The studied samples are essentially composed of plagioclase and clinopyroxene, while opaque mineral(s) and alkali feldspar are present in accessory amounts. Biotite is present in trace amount, while chlorite, tremolite, and sericite occur, in variable amounts, as alteration products. Zeolite and carbonate filled amygdules are observed in a few samples.
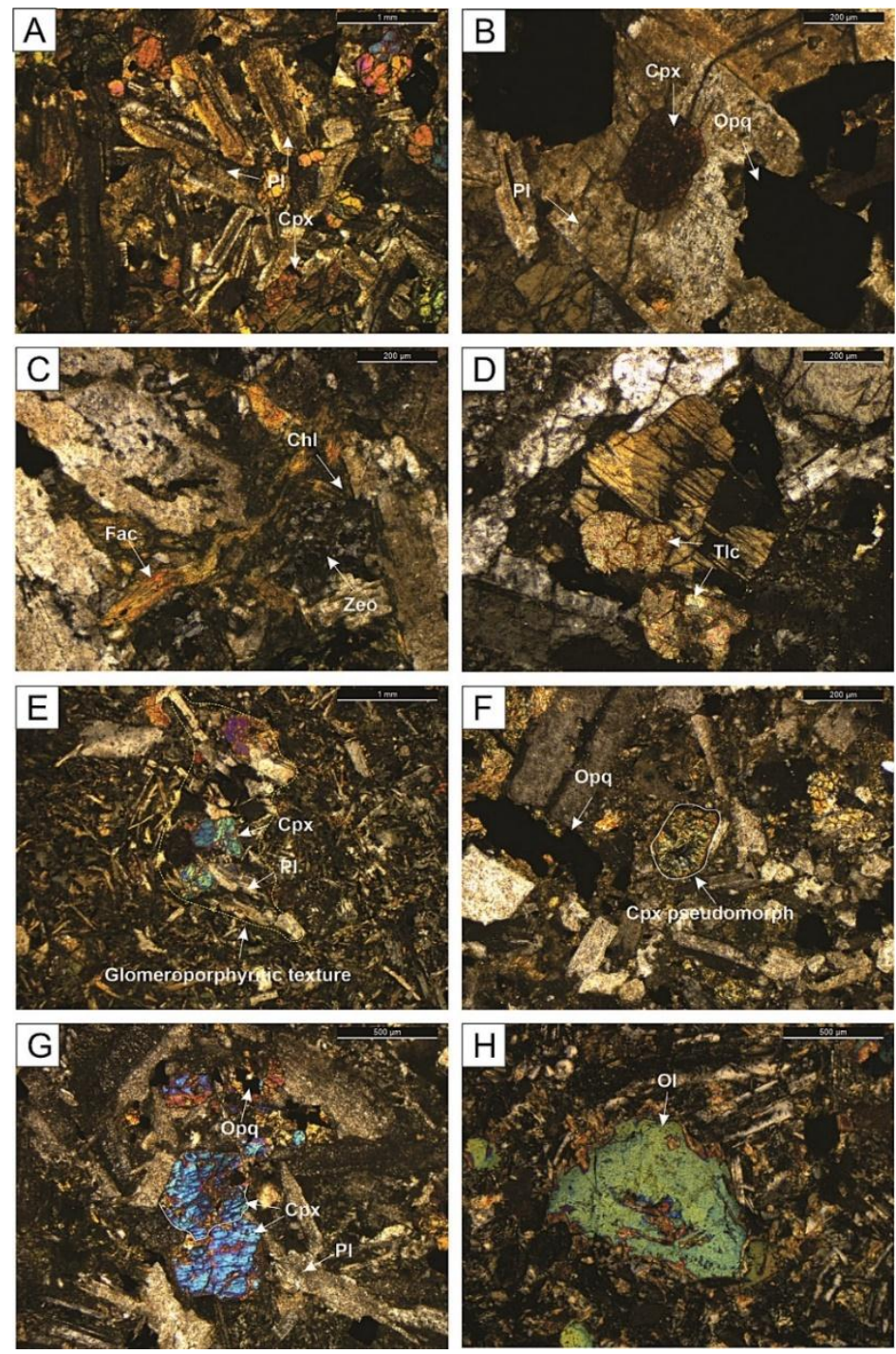

Figure 6: Petrographic features of the rocks of Gwal mélange: $(\mathrm{A})$ plagioclase $(\mathrm{Pl})$ and clinopyroxene $(\mathrm{Cpx}),(\mathrm{B})$ plagioclase $(\mathrm{Pl})$, clinopyroxene $(\mathrm{Cpx})$ and 
opaque grains (Opq), (C) Ferro-actinolite (Fac), chlorite (Chl) and zeolite (Zeo) (D) talc pseudomorphed after olivine (Tlc), (E) plagioclase (Pl) and clinopyroxene (Cpx), (F) opaque minerals (Opq) and pseudomorph after clinopyroxene (Cpx), (G) plagioclase (Pl) and clinopyroxene (Cpx) and opaque grains (Opq), (H) olivine (Ol).

Plagioclase is the most abundant phenocryst in these samples and its size ranges from 250 micrometers to 1.5 millimeters, however, the upper size limit is very rare and does not occur in all samples, and these, relatively, larger crystals are considered as microphenocrysts. Plagioclase is mostly subhedral to euhedral in form, lath shaped, and exhibit Carlsbad twining, however, a minor proportion of crystals also display albite polysynthetic twinning. It occurs in three distinct crystal habits; (i) as lath shaped crystals which are relatively larger than the other two types, ii) very thin or needle-shaped crystals, and iii) relatively smaller, approximately equidimensional crystals (Fig.E). Plagioclase is completely pseudomorphed either by sericite only or by a mixture of sericite, clay, and zeolites and/or prehnite.

Elongated to stubby prisms of subhedral to anhedral clinopyroxene grains occur as an essential mineral in these samples. Clinopyroxene grains are slightly altered to chlorite, however, it is also pseudomorphed by chlorite and ferro-actinolite in some samples (Figure 6F). Chloritized material is present in interstices without any relics. Accessory amount of opaque mineral(s) occurs as subhedral to anhedral discrete grains, as well as interstitial material associated with other minerals (Figure 6F). Subhedral to anhedral grains of clinopyroxene is the second most abundant essential mineral, and its size distribution is similar to that of plagioclase (Figure 6G). It is, also, developed in the interstices between well-developed plagioclase crystals. Chlorite and tremolite occur as clusters of very fine-grained flakes/fibers that exhibit random to preferred orientations.

The accessory amount of olivine is present in the studied samples, and its size distribution is almost similar to that of essential minerals. It is a subhedral to anhedral in the form with a very minor proportion of euhedral grains now pseudomorphed by other minerals. Some of the early formed crystals of olivine show zoning and resorbed boundaries, and a cluster of very fine-grained (unidentifiable) minerals as inclusions (Figure 6G). Minor alteration of olivine to talc is common, while some grains are completely pseudomorphed by talc (Figure 7A). Bowlingite and iddingsite have, also, replaced olivine grains, in some samples (Figure 7B). Accessory amount of opaque mineral(s) occurs as well-developed discrete grains, as well as interstitial material between essential minerals. The trace amount of primary biotite and calcite is also present in these samples. The contact relationship of clinopyroxene with plagioclase is observed in detail and it is concluded that the clinopyroxene is, definitely, crystallized in a minimum of two generations i.e. the first one that is almost euhedral to subhedral in form and crystallized earlier than plagioclase (Figure 7G).
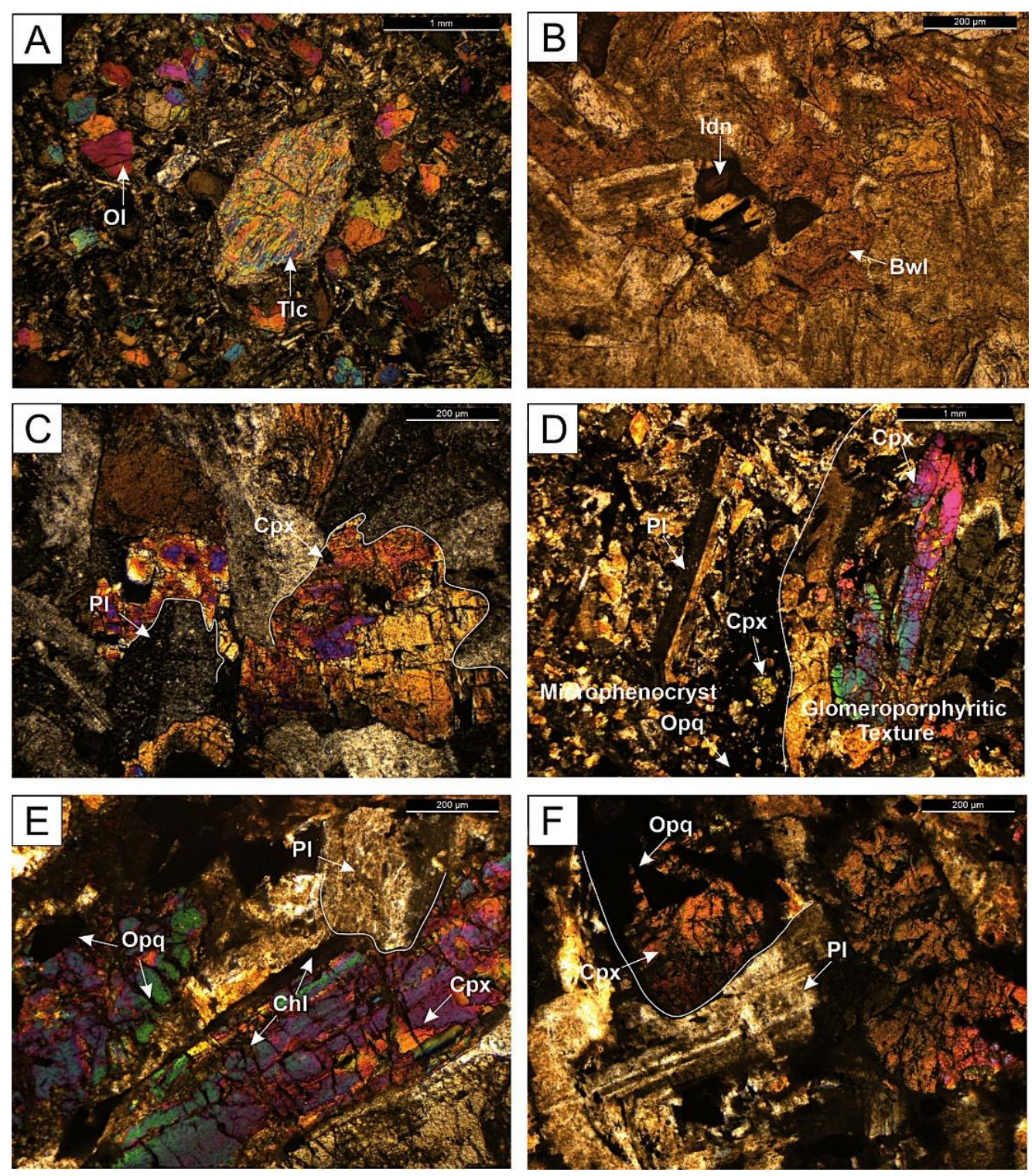

Figure 7: Petrographic features of the rocks of Gwal mélange: (A) olivine (Ol) and talc (Tlc), (B) iddingsite (Idn) and bowlingite (Bow), (C) plagioclase (PI) and clinopyroxene (Cpx), (D) plagioclase (Pl) and clinopyroxene (Cpx), (E) plagioclase (Pl), clinopyroxene (Cpx), chlorite (Chl) and opaque grains $(\mathrm{Opq})$, (F) opaque minerals $(\mathrm{Opq})$ and plagioclase $(\mathrm{Pl})$.

\subsection{Andesite}

Andesite is primarily composed of plagioclase, while clinopyroxene, opaque phases, and alkali feldspar represent the accessory proportion. Biotite makes 
up to trace amount only, and chlorite and sericite are alteration products after pyroxene and feldspars, respectively. The studied sample hypidiomorphic, very fine-grained to fine-grained, and contains a very minor proportion of medium-sized phenocrysts of plagioclase and clinopyroxene, which gives it micro-porphyritic texture (Figure 7D).

Subhedral to euhedral plagioclase is the most dominant mineral. It is oligoclase to andesine in composition. Relatively larger grains are euhedral lath shaped, while relatively smaller grains are subhedral in from (Figure 7D). Carlsbad twinning is associated with relatively larger grains, while others also exhibit albite polysynthetic twinning, and sericite is the most common alteration product. Plagioclase seems to be formed earlier in the crystallization sequence, it can easily be predicted from the contact relationship with the surrounding accessory phases (Figure 7E). Some of the clinopyroxene grains, also, show simultaneous crystallization with early-stage plagioclase (Figure 7F).

Clinopyroxene makes up to 6 percent of the modal mineralogy. The most dominant size population of clinopyroxene ranges from 300 to 600 micrometers, however its overall size range is 100 micrometers to 2.4 millimeters. Larger grains, in this range, are quite a few and considered micro-phenocrysts (Figure 7D). Inclusions of variable-sized opaque minerals are very common in relatively larger grains, and plagioclase inclusions are very rare. Texturally two different forms of opaque mineral(s) are present in accessory amount; i) as subhedral to anhedral discrete fine-grained crystals, and ii) as irregular patches, few millimeters in size, and containing abundant tiny inclusions of felsic phases as well as some clinopyroxene.

\subsection{Discussion}

The Gwal mélange is divided into ultramafic, mafic, hyaloclastite, pelagic sediments and ophicarbonates. Deformation and alteration in the mélange rocks have severely affected their physical and petrological characters. Obduction-related ophiolitic mélanges have a global presence. In Pakistan, these are Bagh Complex lying underneath Muslim Bagh Ophiolite, and nappe of Vezhda Sar underneath Waziristan Ophiolite [28]. Khan reported the obduction, related mélange lies under the Neyriz Ophiolite in Iran. From Turkey, Lycian mélange underneath Lycian Ophiolite, and Aladag mélange lying below PozantiKarsanti Ophiolite are reported by Sarkarinejad and Collins and Robertson, respectively. Hawasina and Hayabi Complexes which are found at the base of Semail Ophiolite Oman possess the same characters as that are the Gwal mélange [29-32].

Harzburgite in the layered mantle peridotite of Gwal mélange essentially consists of olivine and orthopyroxene lacking preferential amount of clinopyroxene. Dunite (now intensively serpentinized) lacks the presence of any pyroxene. Both harzburgite and dunite, unfold the mantle as a depleted in nature rather than fertile and can be residual after severe partial melting of lherzolitic mantle [33]. During the processes of partial melting, the melt may have reacted with residual rock and have precipitated the olivine and orthopyroxene, hence leaving a depleted residual mantle [34]. Serpentinite is the secondary product after olivine in peridotite and is maybe the product of late/post magmatic stages. The mesh structure is usually observed when olivine is completely transformed/altered into serpentine. Cross-fiber veins forming longitudinal lattice shapes enclosing olivine core is the typical micromorphologic feature of a mesh [35]. The estimated proportion of the primary minerals, in the studied samples, reveal that the samples which are composed of 98 percent mesh-serpentine reflects the same amount of primary olivine that is now completely serpentinized, is maybe dunite with 98 percent primary olivine was the parental material for these rocks. The same parent rock is a suitable prediction for the sample-2 (see table 1) with 88 percent meshserpentine and 10 percent relic olivine. The sample which contains 86 percent mesh-serpentine and 10 percent modal abundance of orthopyroxene-bastite in association with a trace amount of $\mathrm{Cr}$-spinel is considered to be an alteration product after $\mathrm{Cr}$-spinel bearing harzburgite.

The volcanic and volcaniclastic rocks in Gwal mélange is just like that found beneath the Khanozai Ophiolite and in the Bagh Complex laying underneath Muslim Bagh Ophiolite. Exposures of the volcanic rocks outcrops are structurally sheeted and pillowed while volcaniclastic rocks are essentially hyaloclastites. As we have no geochemistry data to classify the lavas into mid-oceanic ridge basalt (MORB) and ocean island basalt (OIB) as classified in the Bagh complex Still it could be judged from the lithological assemblages of volcanics, volcaniclastics, chert, pelagic sediments, mudstone and limestone that it may be the southern extent of basalt-chert, and hyaloclastite mudstone units of Bagh Complex exposed beneath the Muslim Bagh ophiolite [9, 36].

Ophicalcites, consisting of serpentine and calcite are determined through the oxygen and carbon isotopes, petrographic and field study in Pyrenean belt (Europe) are usually of three main types. (1) Ultramafic material in a calcite matrix (2) serpentinite or peridotite fracture-filled by calcite and (3) serpentine mineral substituted by calcite unescapably [37]. Their origin is still probed as endogenic and surficial by the different schools of thought. The group preferring their evolution as endogenic divides it as (1) gas seeps originated by mantle, (2) intruded magma, (3) regional and contact metamorphism related, and (4) hydrothermally interacted fluid [38-46]. Another school of thought describes ophicarbonates origin as a surficial process where ultramafic and carbonates are mixed through processes of gravity, tectonic crushing and/or sedimentary reworking [47-54]. Through the petrographic studies, it is determined that the ophicarbonates in the Gwal mélange show pieces of evidence of serpentine replaced by carbonate minerals through the interaction of hydrothermal fluids.

In short, the Gwal mélange is the southern extension of Bagh Complex found underneath the Muslim Bagh Ophiolite which is exposed further south below the Bela ophiolite $[6,37,53]$. The mantle peridotite of the mélange is not fertile in nature which is much like that of the Khanozai peridotite which was determined as depleted in nature and Gwal peridotite may represent the detached masses of Khanozai peridotite [37]. The volcanic and volcaniclastic rocks of the mélange may be the representatives of uppermost parts of ophiolite' crust which might have trimmed off from subducting slab, and are, now combined into Gwal accretionary-wedge [23]. Later on, they may have tectonically emplacement over Indian platform sediments together with overlying ophiolite sheets during the Late Cretaceous $[20,55,56]$.

\subsection{Conclusions}

The above discussion leads to the following conclusions:

1. The Gwal mélange is comprising of large outcrops of ultramafic-mafic rocks, volcanic and volcanoclastic rocks, pelagic sediments and ophicarbonates. Petrographically, the mélange rocks are classified as harzburgite, dunite, wehrlite, serpentinite, gabbro, basalt, and andesite.

2. The origin of ophicarbonate may be due to the gas seeps originated by mantle or as a surficial process where ultramafic rocks and carbonates are mixed through processes of gravity, tectonic crushing, and sedimentary reworking.

3. The Gwal mélange may be the southern extension of Bagh Complex found beneath the Muslim Bagh Ophiolite. The ultramafic rocks of the mélange are much like that of the Khanozai ophiolite' peridotite and may represent its detached blocks. Volcanic and volcanoclastic rocks may be the representatives of the uppermost part of ophiolite crust which might have trimmed off from subducting slab and are, now, part of the Gwal accretionary wedge.

4. The Gwal mélange may have tectonically emplacement over the Indian platform sediments along with overlying the ophiolite sheet during the Late Cretaceous.

\subsection{Acknowledgments}

This research was financially supported by the Higher Education Commission, Pakistan under its National Research Program for Universities (NRPU) Project \# 3593 to the second author.

\section{References}

[1] E. Silver, "Penrose conference report: Melange”. Geology, Vol. 8, Pp. 32-34, 1980.

[2] K.J. Hsü, "Principles of melanges and their bearing on the Franciscan-Knoxville paradox", Geological Society of America Bulletin, Vol. 79(8), Pp. 1063$1074,1968$. 
connection to subduction processes", Mélanges: processes of formation and societal significance: Geological Society of America Special Paper, Vol. 480, Pp. 117-141, 2011.

[4] J. Shervais, "Serpentinite matrix mélange: Implications of mixed provenance for mélange formation", Special Paper of the Geological Society of America. 2011.

[5] R. Myhill, "Constraints on the evolution of the Mesohellenic Ophiolite from. Mélanges", Processes of Formation and Societal Significance, Vol. 480, Pp. 75, 2011.

[6] E. Gnos, A. Immenhauser, and T. Peters, "Late Cretaceous/early Tertiary convergence between the Indian and Arabian plates recorded in ophiolites and related sediments", Tectonophysics, Vol. 271(1-2), Pp. 1-19, 1997.

[8] E. Gnos, M. Khan, and K. Mahmood, Bela oceanic lithosphere assemblage and its relation to the Reunion hotspot. terra nova-oxford-, Vol. 10, Pp. 90-95, 1998.

[9] M.I. Kakar, "Supra-subduction zone tectonic setting of the Muslim Bagh Ophiolite, northwestern Pakistan: insights from geochemistry and petrology", Lithos, Vol. 202, Pp. 190-206, 2014.

[10] A. Gansser, "Reconnaissance visit to the ophiolites in Baluchistan and the Himalaya”, Geodynamics of Pakistan, Pp. 193-213, 1979.

[11] F. Allemann, "Time of emplacement of the Zhob Valley ophiolites and Bela ophiolites, Baluchistan (preliminary report). Geodynamics of Pakistan", Geological Survey of Pakistan, Quetta, Pp. 215-242, 1979.

[12] M. Iqbal, "Integration of Satellite Data and Field Observations in Pishin Basin, Balochistan", Pakistan Journal of Hydrocarbon Research, Vol. 14, Pp. 1$17,2004$.

[13] A.K. Kasi, “Revised lithostratigraphy of the Pishin Belt, northwestern Pakistan”, Journal of Himalayan Earth Science, Vol. 45(1), 2012.

[14] R.H. Siddiqui, "Geology, Petrochemistry and tectonic evolution of Muslim Bagh ophiolite complex, Pakistan", in Proc. Of Geoscience Colloquium, Geoscience Lab., GSP. 1996.

[15] I.A. Jadoon, and A. Khurshid, "Gravity and tectonic model across the Sulaiman fold belt and the Chaman fault zone in western Pakistan and eastern Afghanistan", Tectonophysics, Vol. 254(1-2), Pp. 89-109, 1996.

[16] G. Sarwar, "Tectonic setting of the Bela Ophiolites, southern Pakistan”, Tectonophysics, Vol. 207(3-4), Pp. 359-381, 1992.

[17] Z. Ahmed, "Nd-and Sr-isotopic constraints and geochemistry of the Bela Ophiolite-Melange complex, Pakistan", International Geology Review, 38(4), Pp. 304-319, 1996.

[18] E. Gnos, “Bela oceanic lithosphere assemblage and its relation to the Reunion hotspot”, Terra Nova, Vol. 10(2), Pp. 90-95, 1998.

[19] K. Khan, Mahmood, and J.F. Casey, "Mapping of Muslim Bagh ophiolite complex (Pakistan) using new remote sensing, and field data", Journal of Asian Earth Sciences, Vol. 30(2), Pp. 333-343, 2007.

[20] M.I. Kakar, "Supra-subduction zone tectonic setting of the Muslim Bagh Ophiolite, northwestern Pakistan: insights from geochemistry and petrology", Lithos, Vol. 202, Pp. 190-206, 2014.

[21] Asrarullah, "Ophiolites in Pakistan: an introduction. Geodynamics of Pakistan”, Geological Survey of Pakistan, Quetta, Vol. 181, Pp. 192, 1979.

[22] Ali, "Petrology And Major Element Geochemistry Of Volcanic Rocks Beneath The Khanozai Ophiolite, Balochistan, Pakistan”, Bahria University Research Journal of Earth Sciences, Vol. 4(1), Pp. 40-45, 2019.

[23] Haq, "Petrology And Major Element Geochemistry Of Mantle RocksFrom Khanozai Ophiolite, Northern Balochistan, Pakistan", Bahria University Research Journal of Earth Sciences, Vol. 4(1), Pp. 26-32, 2019.

[24] H. Ullah, and A. Khan, "Petrology and geochemistry of chromitite and peridotite from khanozai ophiolite, northern balochistan, pakistan", Bahria University Research Journal of Earth Sciences, Vol. 4(1), Pp. 60-69, 2019.

[25] A. Popal, M. Ishaq Kakar, and M. Khan, "Geology and petrography of gabbroic rocks from Khanozai Ophiolite, Northwestern Pakistan", International Research Journal of Earth Sciences, Vol. 7(3)(3), Pp. 10-22, 2019.

[26] M. Cheema, “Cainozoic. Stratigraphy of Pakistan”, Memoirs of the Geological Survey of Pakistan, Quetta, Vol. 12, Pp. 1-138, 1977.

[27] M. Humayon, R.J. Lillie, and R.D. Lawrence, "Structural interpretation of the eastern Sulaiman foldbelt and foredeep, Pakistan", Tectonics, vol. 10(2), Pp. 299-324, 1991.

[28] M. Warraich, "Geology and structure of the calcareous zone in the Muslim Bagh in the Qilla Saifullah area, Balochistan", Geologica, Vol. 1, Pp. 61-75, 1995

[29] Khan , "Petrology of the dykes from the Waziristan Ophiolite, NW Pakistan", Journal of Asian Earth Sciences, Vol. 29(2-3), Pp. 369-377, 2007.

[30] K. Sarkarinejad, "Structural and microstructural analysis of a palaeo-transform fault zone in the Neyriz ophiolite, Iran", Geological Society, London, Special Publications, 218(1), Pp. 129-145, 2003.

[31] A.S. Collins, and A.H. Robertson, 1997. Lycian melange, southwestern Turkey: an emplaced Late Cretaceous accretionary complex. Geology, Vol. 25(3), Pp. 255-258, 1997.

[32] Y. Dilek, "Structure and petrology of Tauride ophiolites and mafic dike intrusions (Turkey): Implications for the Neotethyan ocean", Geological Society of America Bulletin, Vol. 111(8), Pp. 1192-1216, 1999.

[33] A. Robertson, and M. Searle, "The northern Oman Tethyan continental margin: stratigraphy, structure, concepts and controversies", Geological Society 
London, Special Publications, Vol. 49(1), Pp. 3-25, 1990.

[34] M.B. Baker, and J.R. Beckett, "The origin of abyssal peridotites: a reinterpretation of constraints based on primary bulk compositions", Earth and Planetary Science Letters, Vol. 171(1), Pp. 49-61, 1999.

[35] N. Kelemen, Shimizu, and V. Salters, "Extraction of mid-ocean-ridge basalt from the upwelling mantle by focused flow of melt in dunite channels", Nature, Vol. 375(6534), Pp. 747, 1995.

[36] J. Delvigne, "Olivines, their pseudomorphs and secondary products", Stiboka, 1979.

[37] J. Mengal, "The lithology and structure of a Mesozoic Sedimentary-igneous assemblage beneath the Muslim Bagh ophiolite, Northern Balochistan, Pakistan", Bulletin of the Geological Survey of Japan, Vol. 45, Pp. 51-61, 1994.

[38] C. Clerc, "Ophicalcites from the northern Pyrenean belt: a field, petrographic and stable isotope study", International Journal of Earth Sciences, Vol. 103(1), Pp. 141-163, 2014

[39] E. Bonatti, “Ultramafic-carbonate breccias from the equatorial Mid Atlantic Ridge”, Marine Geology, Vol. 16(2), Pp. 83-102, 1974.

[40] J. Haggerty, "Petrology and geochemistry of neocene sedimentary rocks from mariana forearc seamounts: Implications for emplacement of the seamounts", Seamounts, Islands, and Atolls, Vol. 43, Pp. 175-185, 1987.

[41] Kelemen, "Drilling Mantle Peridotite along the Mid-Atlantic Ridge from 14 to 16 N: Sites", Proc. ODP, Init. Repts., Pp. 1268-1275, 2004.

[42] E.B. Basley, and W.J. Mccallien, "Some aspects of the Steinmann trinity, mainly chemical”, Quarterly Journal of the Geological Society, Vol. 116(1-4), Pp. $365-395,1960$

[43] H.P. Cornelius, H.P., "Petrographische Untersuchungen in den Bergen zwischen Septimer-und Julierpass", Inaugural-Dissertation... von Hans Peter Cornelius. E. Schweizerbart, 1912.

[44] T. Peters, "A water-bearing andradite from the Totalp serpentine (Davos, Switzerland): American Mineralogist", Journal of Earth and Planetary Materials, Vol. 50(9), Pp. 1482-1486, 1965.

[45] V. Trommsdorff, B.W. Evans, and H.R. Pfeifer, "Ophicarbonate rocks-metamorphic reactions and possible origin”, Archives des Sciences, Vol. 33, Pp. $361-364,1980$

[46] D. Lavoie, and P.A. Cousineau, "Ordovician ophicalcites of southern Quebec Appalachians; a proposed early seafloor tectonosedimentary and hydrothermal origin", Journal of Sedimentary Research, Vol. 65(2a), Pp. 337-347, 1995.

[47] D. Artemyev, and V. Zaykov, "The types and genesis of ophicalcites in Lower Devonian olistostromes at cobalt-bearing massive sulfide deposits in the West Magnitogorsk paleoisland arc (South Urals)", Russian Geology and Geophysics, Vol. 51(7), Pp. 750-763, 2010.

[48] D. Mccaffrey, "Hybrid event beds generated by local substrate delamination on a confined basin floor, 2. 2016.

[49] A. Knipper, "Ophicalcites and some other types of breccias accompanying the preorogenic formation of ophiolite complex", Geotektonika, Vol. 2, Pp. 50-66. 1978.

[50] D. Bernoulli, and H. Weissert, "Sedimentary fabrics in Alpine ophicalcites, south Pennine Arosa zone, Switzerland”, Geology, Vol. 13(11), Pp. 755-758, 1985.

[51] G.L., Früh-Green, H. Weissert, and D. Bernoulli, "A multiple fluid history recorded in Alpine ophiolites", Journal of the Geological Society, Vol. 147(6), Pp. 959-970, 1990

[52] B.E. Treves, and G.D. Harper, "Exposure of serpentinites on the ocean floor: sequence of faulting and hydrofracturing in the Northern Apennine ophicalcites", Ofioliti, Vol.19(4), Pp. 435-466, 1994.

[53] Treves, D. Hickmott, and G. Vaggelli, "Texture and microchemical data of oceanic hydrothermal calcite veins, Northern Apennine ophicalcites", Ofioliti, Vol. 20(2), Pp. 111-122, 1995.

[54] A. Knipper, and A.Y. Sharaskin, "Exhumation of Upper-Mantle and Lower Crustal Rocks through Rifting", Geotectonics c/c of Geotektonika, Vol. 32, Pp. 354-365, 1998

[55] W. Xiao, "A review of the western part of the Altaids: a key to understanding the architecture of accretionary orogens", Gondwana Research, Vol. 18(23), Pp. 253-273, 2010.

[56] T. Naka, "Mesozoic sedimentary-igneous Complex, Bagh complex, in the Muslim Bagh Area, Pakistan. opening and closing ages of the Ceno-Tetheyan branch", Proceedings of Geoscience Colloquium, Geoscience Laboratory, Geological Survey of Pakistan. 1996. 